\title{
TÁ RINDO DE QUÊ? DEBATE EM TORNO DE CHARGES CONTROVERSAS
}

\author{
WHAT ARE YOU LAUGHING AT? DEBATE AROUND A \\ CONTROVERSIAL CARTOONS
}

Tamiris Machado Gonçalves ${ }^{66}$

RESUMO: A charge é um gênero discursivo que pode suscitar inúmeras polêmicas. Em nossa sociedade, há, sobretudo, maior possibilidade de controvérsia quando esse gênero dialoga com discursos que versam sobre morte. Tendo em vista tais consideraçôes, o presente artigo tem o objetivo de: (a) examinar de que forma diferentes vozes sociais que atravessam charges polêmicas sobre morte trágica se engendram e refletem e refratam sentidos no discurso e (b) discutir sobre discursos-resposta que emergem a partir das charges polêmicas em questâo. Foram delimitados como objetos de análise duas charges, uma de Marco Aurélio e outra de Chico Caruso, e discursos-resposta a elas relacionados, todos veiculados em meio digital em 2013 e que fizessem referência a fatos divulgados pela mídia brasileira também nesse ano. Como embasamento teórico, recorre-se às ideias postuladas por Bakhtin e seu Círculo, especialmente os conceitos de gêneros discursivos, enunciado, signo ideológico, acento de valor e vozes sociais. Espera-se, com as discussōes levantadas, contribuir para socializar as ideias do Círculo de Bakhtin de modo a viabilizar o entendimento da linguagem em uso a partir da análise dos mais variados discursos sociais.

Palavras-chave: Teoria bakhtiniana; Discurso; Charge.

ABSTRACT: The cartoon is a discursive genre that can raise many controversies. In: our society, there is, above all, greater possibility of controversy when this genre dialogue with discourses which deal with death. In: view of such considerations, this paper aims to (a) investigate how the different social voices that go through controversial cartoon engender themselves and reflect and refract senses in the discourse and (b) talk about discourse-response that come out from controversial cartoons. We chose as objects of analysis two cartoons, by Marco Aurélio and by Chico Caruso, and discourses-response related to it, all broadcasting in digital form in 2013 and that made reference to facts released by the Brazilian media also this year. As a theoretical framework, we use the ideas postulated by Mikhail Bakhtin and his Circle, especially the concepts of discursive genres, enunciation, ideological sign, evaluative accent and social voices. We hope, with raised discussions, to contribute to socialize the ideas from the Circle

66 Doutoranda em Letras, área de concentraçăo em Linguística, da Pontifícia Universidade Católica do Rio Grande do Sul - PUCRS. Bolsista CNPq. Correio Eletrônico: mtamiris@gmail.com 
of Bakhtin in order to facilitate the understanding of the language in use through the analysis of the most diverse social discourses.

Keywords: Bakhtinian Theory; Discourse; Cartoons.

\section{INTRODUÇÃO}

Reflexóes em torno da linguagem têm marcado distintas áreas do saber. Em quadros teóricos diversificados, com princípios e métodos diferentes, compreender a linguagem é fascinante. Centrando o olhar na construçáo dos sentidos no discurso, ancorando-se nos pressupostos do Círculo de Bakhtin, neste artigo é colocada a questâo de como se dá a construçâo dialógica dos sentidos no discurso chargístico. ${ }^{67}$

A charge é um gênero que se constitui a partir de acontecimentos sociais que sejam contemporâneos a ela. Assim sendo, faz-se oportuno o questionamento de como se dá a construçâo dialógica de sentidos, considerando a produçâo e recepçâo do discurso, em charges tidas como polêmicas por tratarem sobre mortes trágicas.

Nessa perspectiva, os objetivos deste trabalho sâo (a) examinar de que forma diferentes vozes sociais que atravessam charges polêmicas sobre morte trágica se engendram e refletem e refratam sentidos no discurso e (b) discutir sobre discursos-resposta que emergem a partir das charges polêmicas em questâo. Delimitou-se como recorte de pesquisa duas charges, uma de Marco Aurélio e outra de Chico Caruso e discursos -resposta a ela relacionados, todos veiculados em meio digital em 2013 e que fizessem referência a fatos divulgados pela mídia brasileira também nesse ano.

A fim de obter uma análise dialógica que envolva o material discursivo sob um viés sociológico, como embasamento teórico, recorre-se às ideias postuladas por Bakhtin e seu Círculo, especialmente os conceitos de gêneros discursivos, enunciado, signo ideológico, acento de valor e vozes sociais.

Quanto à organizaçâo deste artigo, após estas consideraçôes iniciais, será apresentada uma explanaçăo dos conceitos bakhtinianos, sobretudo das noçóes de enunciado, signo ideológico, acento de valor e vozes sociais. Depois, será feita a análise do recorte de pesquisa, com vistas a compreender a produçâo de sentidos em circulaçáo. Ao final, serâo apresentadas as consideraçôes finais que visam a expressar a conclusibilidade necessária para dar lugar à atitude responsiva de outros pesquisadores que desejarem dialogar com este material de estudo.

\section{TEORIA DIALÓGICA DO DISCURSO}

O discurso, conforme as ideias do Círculo, é tomado como a língua/linguagem concreta e viva. Por meio das enunciaçôes, o discurso constitui-se como um fenômeno

67 Recorte (revisado e ampliado) da dissertaçâo de mestrado Vozes sociais em confronto: sentidos polêmicos construídos discursivamente na produçăo e recepçáo de charges, defendida em 2015. Disponível em: <http://repositorio.pucrs.br/dspace/bitstream/10923/7160/1/000466609-Texto\%2BCompleto-0.pdf〉 
social ${ }^{68}$ complexo, advindo das relaçóes humanas mais variadas. Amparado no curso do tempo, o discurso está em diálogo com já-ditos, discursos passados, bem como com a projeçăo de discursos-resposta, discursos futuros solicitados pela situaçáo enunciativa. Sua complexidade está na diversidade de vozes que o constituem. Essas vozes săo as apreciaçôes, os pontos de vista, as valoraçóes que o sujeito exprime frente ao mundo que a ele se coloca diante de seus parceiros na comunicaçăo discursiva. Isso significa dizer que o discurso se nutre de enunciados concretos produzidos por sujeitos históricos sempre em relaçăo dialógica e sob posiçóes avaliativas que movimentam a permanente renovaçáo dos sentidos (BAKHTIN 2008, pp. 71; 86-89).

Em seu caminho até o objeto, o discurso encontra-se com discursos outros que lhe antecedem e lhe sucedem. Essa orientaçâo dialógica é característica de todo discurso e acontece necessariamente na enunciaçăo concreta. A charge, o objeto de estudo deste artigo, é um gênero que se origina de fatos sociais e os (re)significa para construir seu próprio discurso que, engendrado pela posiçăo avaliativa de seu locutor situado em um tempo e espaço definidos, irá colocar-se como único na cadeia discursiva.

O discurso, portanto, é composto de uma multiplicidade de vozes advindas das diferentes experiências de interaçăo humana. É essa diversidade de vozes, pois, que leva o Círculo a considerar que a linguagem nâo é reflexo direto da realidade dos fatos da vida, mas materializa-se como construçăo discursiva dos fatos sociais e deixa entrever, a partir dos signos ideológicos, as apreciaçôes valorativas sobre o mundo em que o ser humano está inserido.

Os signos ideológicos năo sâo um decalque da realidade - porque essa é uma construçáo semiótica -, eles a refletem (reverberam a realidade a que apontam) e refratam (săo interpretados pelo locutor de acordo com suas múltiplas vivências). A esse respeito, Faraco (2009, pp. 50-53) observa que os signos podem apontar para a materialidade do mundo, sua realidade externa, mas esse processo acontece de modo refratado. Explica o autor que a noçấo de refraçăo diz respeito às valoraçóes que se inscrevem no signo, sáo os múltiplos modos de semantizaçâo dos fatos da vida social, gerados a partir das experiências humanas com base na carga história que carregam, devido à heterogeneidade de sua práxis. Em vista disso, no processo de constituiçấo dos sentidos, entâo, temos dois movimentos imbricados: o reflexo e a refraçâo.

Nessa perspectiva, o sentido do signo năo é imanente, năo é dado por si. Os sentidos, pois, sâo construçôes humanas experienciadas a partir de grupos socialmente organizados e só podem ser plenos na enunciaçăo. Devido à multiplicidade e à heterogeneidade das relaçóes humanas, os signos estăo sempre carregados das interpretaçōes do mundo que se produzem na e por meio da enunciaçăo. As relaçóes dialógicas alimentam essas interpretaçōes do mundo, atualizando, no discurso, o que as relaçóes lógicas (fenômenos sintáticos, semânticos e lexicais) sinalizam como possibilidade de sentido.

A experiência social, a cultura, é o que preenche o signo - daí essa especificaçáo (ideológico) que faz toda a diferença ao demarcar que năo mantém relaçăo com o conceito saussuriano de signo, ao qual, em Marxismo e Filosofía da Linguagem, o Círculo

68 Em O discurso no romance, Bakhtin (1998, p. 71) ressalta que o discurso é um fenômeno social. 
tece crítica fundamentando que essa identidade imutável e sistemática lhe confere caráter de sinal (2009, p. 96). Como na natureza nada é ideológico por si, sâo as relaçôes sociais, e as valoraçōes construídas nessas relaçōes, que dăo a valência dos signos. Nas palavras de Bakhtin/Volchínov (2009, pp. 32-33):69

[...] todo o produto natural, tecnológico ou de consumo pode tornar-se signo e adquirir, assim, um sentido que ultrapasse suas próprias particularidades. Um signo năo existe apenas como parte de uma realidade; ele também reflete e refrata uma outra. Ele pode distorcer essa realidade, ser-lhe fiel, ou apreendê-la de um ponto de vista específico, etc. Todo o signo está sujeito aos critérios de avaliaçăo ideológica (isto é, se é verdadeiro, falso, correto, justificado, bom, etc.). O domínio ideológico coincide com o domínio dos signos: sâo mutuamente correspondentes. Ali onde o signo encontra-se, encontra-se também o ideológico.

Dessa maneira, o conceito de signo ideológico implica o de acento de valor, isto é, um juízo crítico expresso por um sujeito circunscrito em determinada cultura. Quando a ideologia atravessa um objeto (concreto ou abstrato), tem-se um signo ideológico.

Ocorre que a construçăo dos objetos é ela própria delineada pelo traço axiológico porque essa é uma característica de todo discurso. Como o aspecto social é o eixo norteador da teoria dialógica do discurso, a linguagem edifica-se a partir da noçáo de relaçōes sociais, que advinda de sujeitos situados em um tempo e um espaço definidos, constituem o que o Círculo chama de índices de valor, que justamente é esse acento de valor compartilhado socialmente.

Assim, todos os enunciados que compóem a entidade maior que é o discurso săo atravessados por um acento de valor - que na teoria aparece com distintos nomes: valoraçăo, ideologia, acento de valor, expressividade. O importante é saber que o adjetivo ideológico que acompanha o termo signo lembra que tudo o que é ideológico é um signo. Como o discurso é permeado de signos ideológicos, nâo há discurso neutro, isento de uma valoraçăo - nessa lógica năo existem signos, nem palavras, nem enunciados neutros. A explicaçăo está fixada na constituiçăo social da linguagem.

Outro argumento é que todo signo encontra-se na cultura imaterial, ou seja, em alguma das instancias superestruturais como a religiăo, a filosofia, as artes, a política, etc. "[...] Cada campo da criatividade ideológica tem seu próprio modo de orientaçáo para a realidade e refrata a realidade à sua própria maneira" (BAKTHIN/ VOLOCHÍNOV 2009, p. 33). Isso significa dizer que cada campo forma seu teor axiológico, compondo índices de valor social determinados e, justamente nessa ótica, é que náo há neutralidade porque o signo nâo só reflete, mas refrata a realidade, dando vida a pontos de vista.

A charge é um gênero discursivo que dialoga com discursos que lhe săo contemporâneos. Motivada por fatos sociais, a charge parte de signos ideológicos presentes em discursos que estăo circulando no meio social e os ressignifica, isto é, atribui a eles

69 Neste artigo, nâo se entra na discussâo acerca da autoria dos textos considerados disputados. Assim sendo, citamos os nomes conforme as referências consultadas apresentam. No caso de Marxismo e filosofía da linguagem, por exemplo, temos um autor, mas a mençăo de dois nomes, por isso Bakhtin/ Volochínov. Como a questâo autoral discute se um ou outro é o autor, náo acreditando em dupla autoria, os verbos sâo colocados no singular - a julgar pela própria apresentaçâo do livro feita por Roman Jakobson que traz verbos no singular. 
significados outros quando os realoca no contexto de seu próprio discurso. Dessa maneira, elementos verbais e náo verbais passam a ter uma valoraçăo própria a partir do contexto da charge. Claro que isso acontece do ponto de vista de sua produçăo porque o chargista cria, a partir do mosaico de vozes sociais, seu próprio discurso. No momento de sua recepçăo, por outro lado, o leitor pode valorar os elementos da charge de maneira diferente daquela pensada pelo chargista, haja vista que sua leitura pode estar ancorada em fios discursivos diferentes daqueles selecionados pelo autor da charge.

De modo geral, talvez porque a caricatura seja um traço que pode integrar o gênero, a charge é compreendida como um discurso de humor; é comum que as pessoas associem a charge ao burlesco, ao satírico, ao risível. Alguns dicionários fazem o registro do conceito charge como ilustraçâo ou desenho de caráter humorístico ${ }^{70}$ (Priberam), ilustraçâo ou caricatura de caráter humorístico, ${ }^{71}$ registrando essa valoraçấo social recorrente.

Se pensarmos na charge de modo mais amplo, percebemos que ela é um gênero que pode ter como um efeito de sentido o humor, mas seu foco é outro. Dizer que a charge pode ter como resultado um efeito de sentido de humor é diferente de entender que o riso é a finalidade da charge. Sua funçăo primeira é a crítica, arquitetada com o auxílio de diferentes efeitos de sentido -ironia, choque, espanto, denúncia - o humor é apenas um deles.

\section{COMPREENDENDO A RECEPÇÃO DE CHARGES SOBRE MORTE TRÁGICA}

A primeira charge que vamos analisar é de autoria de Marco Aurélio e foi publicada no jornal Zero Hora do dia 29 de janeiro de 2013. Com a legenda "Uma nova vida", em apenas um quadro, a charge apresenta uma fila de estudantes frente a uma instituiçâo denominada Universidade de Sáo Pedro - USP. Na cena, da porta do edifício, São Pedro - a julgar pela posiçấo que ocupa (é quem está na porta central com uma lista chamando aqueles que estăo na fila para entrar no prédio), pela auréola que indica sua santidade e pela barba característica do apóstolo cristâo - recebe e direciona os jovens de acordo com a graduaçâo que cursavam. No canto esquerdo inferior, podemos ver a Terra, indicando que a cena acontece em outro lugar que náo o nosso planeta. Há a imagem de um anjo e nuvens na cor azul claro contornam a cena. Essas nuvens, pelo contexto apresentado, podemos dizer que representam o céu, conforme vemos na figura 1.

70 Disponível em:<https://www.priberam.pt/DLPO/charge>. Acesso em: 16 de março de 2016.

71 Disponível em: <https://dicionariodoaurelio.com/charge>. Acesso em: 16 de março de 2016. 
Figura 1 - Uma nova vida

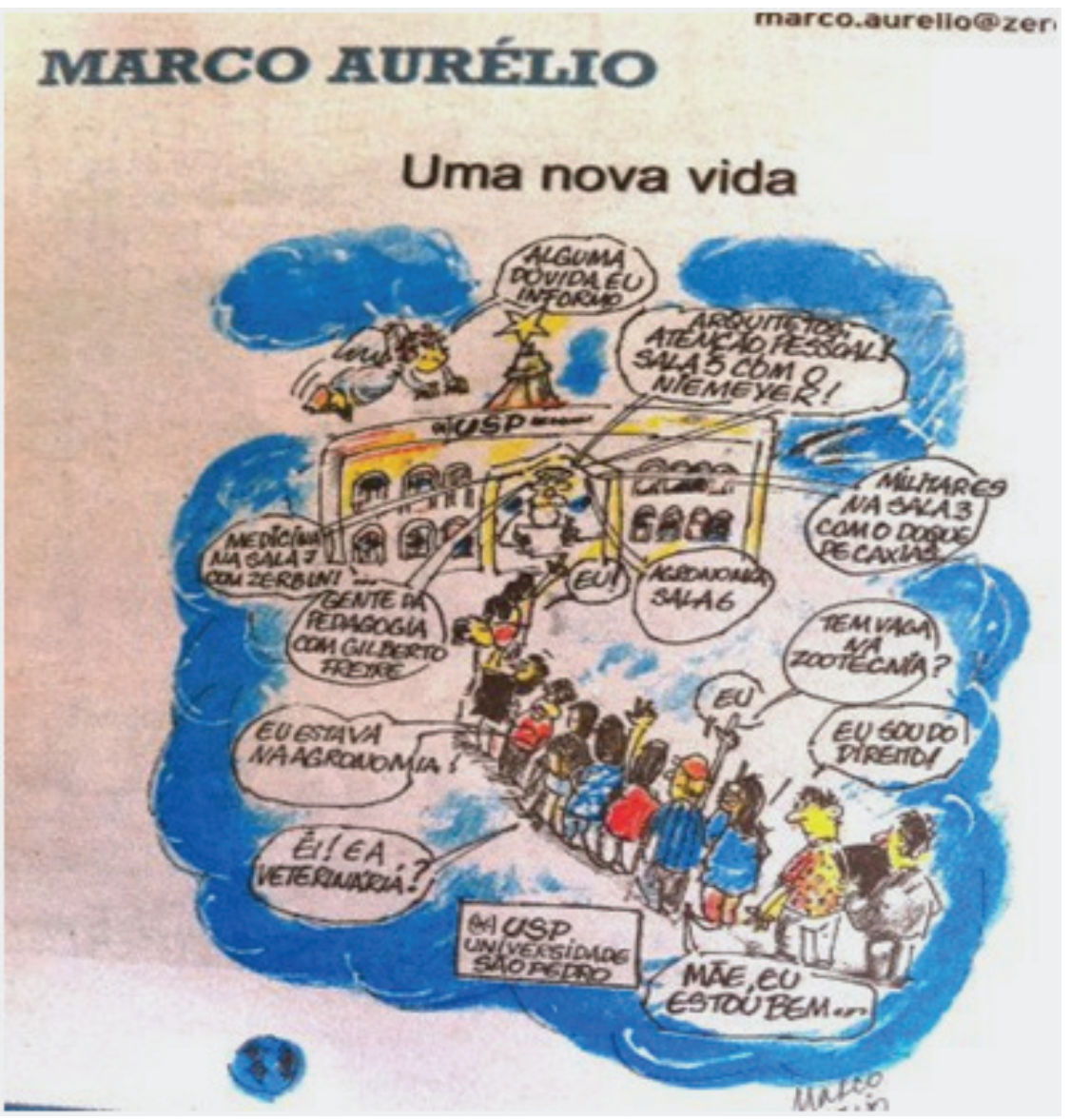

Fonte: Zero hora, 29/01/2013

A charge apresentada dialoga com vozes sociais que enunciam uma tragédia ocorrida na cidade de Santa Maria no Estado do Rio Grande no Sul. No dia 27 de janeiro de 2013 , cerca de 240 pessoas morreram devido a um incêndio em uma casa noturna da regiăo. Segundo o site de notícias $G 1,^{72}$ a festa tinha como público-alvo jovens, sobretudo, universitários.

A charge de Marco Aurélio traz em sua composiçâo discursos que remetem ao acidente ocorrido na cidade gaúcha. Isso é percebido através dos elementos verbais, como as palavras universidade, jovens e céu, e năo verbais que compóem a charge. Tais signos refletem e refratam elementos - o prédio que aparece, nomeado de USP, que, além de Universidade Săo Pedro, também remete à Universidade de Săo Paulo (talvez em alusăo a maior universidade pública do país; tendo-a, talvez, como um signo ideológico para o conceito de universidade); a grande quantidade de jovens, em fila, reforçando a ideia de ingresso de massa humana no céu; a ordenaçăo dos jovens a partir da ocupaçăo e/ou especialidade - que constituem o discurso e se engendram na

72 Disponível em: <http://g1.globo.com/rs/rio-grande-do-sul/tragedia-incendio-boate-santa-maria/ platb/>. Acesso em: 16 de maio 2014. 
construçăo dos sentidos, via vozes sociais com as quais a charge dialoga: a tragédia da boate Kiss em Santa Maria.

Podemos também perceber no discurso da charge de Marco Aurélio vozes religiosas a partir da presença dos signos ideológicos que refletem e refratam a crença espiritual. A legenda "Uma nova vida" faz mençăo a vozes sociais que apresentam uma visăo de que existe outra condiçấo de vida além dessa que temos no planeta Terra. O enunciado "Uma nova vida" é acentuado valorativamente, de modo a considerar que aqueles jovens que morreram no incidente estáo vivos em outro plano que nâo o material. De certa forma, săo produzidos efeitos de sentidos de conforto e consolo projetados a interlocutores diretamente ligados aos jovens, e também direcionado às pessoas que se comoveram com o fato - que seriam o interlocutor potencial dessa charge.

A partir desses signos, é possível também, mais especificamente, associar os enunciados à esfera discursiva do catolicismo, uma vez que existe nesse campo a crença de que, quando as pessoas morrem, vâo para o céu e săo amparadas por santos e anjos - signos presentes na charge. Para justificar essa associaçăo, podemos mencionar a figura com barba, asas e auréola, que se encontra na charge na porta de entrada do prédio, como sendo a imagem de Sáo Pedro, santo da igreja católica, que foi culturalmente nominado como "porteiro" dos céus, devido a uma passagem do Evangelho de Matheus em que Jesus diz que dará a Pedro as chaves do céu.

Esses signos ideológicos, além de refletirem elementos da doutrina católica, podem refratar a ideia de que a morte năo é o fim, pois ao morrer seremos auxiliados por entidades benevolentes capazes de nos cuidar e orientar, de acordo com os católicos. Essa valoraçấo existe na sociedade e pode, em muitos casos, servir de amparo àqueles que se veem sofrendo por alguma perda - como é o caso dos familiares e conhecidos dos vitimados. Nessa perspectiva, é valorado o enunciado "Măe, eu estou bem...", que aparece na charge e ressoa vozes sociais que respondem à preocupaçâo dos familiares em razăo da perda.

O locutor projetado no discurso, isto é, o chargista, materializa, nesse enunciado, sua atitude responsiva ativa frente às vozes sociais que fazem circular comportamentos característicos de situaçóes específicas: a desolaçáo dos familiares diante da perda inesperada de um ente querido, no caso jovens, a partir de uma tragédia coletiva. Essa condiçăo é norteada por valores fixados na sociedade e, conforme nota Volochínov (2011, p. 159), essas sâo enunciaçôes subentendidas que nâo necessitam ser enunciadas porque surgem como uma valoraçăo social intrínseca ao fenômeno que expressam. Assim é o caso da dor dos familiares e todos os discursos cobertos com essa tonalidade.

Nessa perspectiva, em nossa sociedade, o fato da morte carrega consigo vozes de dor e sofrimento e as valoraçôes que rodeiam esse fenômeno já estăo presentes na cadeia discursiva. Elas organizam seus atos correspondentes.

Assim, a charge dialoga com os discursos que têm como tema a tragédia de Santa Maria, mas também dialoga com tantos outros discursos que reverberam o tópico da morte, da perda. Seu interlocutor, portanto, é tanto quem se sensibiliza com o ocorrido na cidade gaúcha quanto quem diretamente está relacionado às vítimas. Isso é o que podemos depreender a partir da construçâo composicional e arquitetônica que a charge apresenta através de seus elementos verbo-visuais. 
Os sentidos em circulaçăo na charge emergem do momento de dor em que a sociedade estava inserida por razăo do incêndio e do número de mortos e feridos. A charge, publicada no dia 29 de janeiro, dois dias após o incidente, năo teve uma boa repercussăo. Isso pode ser associado à situaçăo de comoçăo e, ao mesmo tempo, de revolta pela qual estava passando a sociedade brasileira, especialmente a santa-mariense e gaúcha. Em respeito às vítimas e seus familiares, foi decretado luto em Santa Maria e em cidades gaúchas como Lavras, Tupanciretă e Itaqui. ${ }^{73}$

A charge, como gênero discursivo, muitas vezes é entendida como um discurso de humor e pode năo ser bem aceita justamente por esse motivo. Se entendida dessa forma, é passível de entendimento o repúdio, já que se vivia uma situaçâo de luto, em que, de acordo com a cultura em que estamos inseridos, náo cabe o humor frente à morte. No entanto, em nosso entendimento, a julgar pelos elementos que a constituem, a charge em foco năo trabalha com o humor.

Quanto à repercussăo da charge, em meio a esse cenário concreto, o jornal Zero Hora publicou diversas notícias sobre o incidente e na coluna de opiniấo foi veiculada a charge em questăo. Após receber críticas de leitores, o jornal gaúcho a retirou da ediçâo on-line. O blogue $O$ diarista, que costuma expor charges de Marco Aurélio e outras publicaçōes do grupo RBS, empresa responsável pelo jornal Zero Hora, filiada à Rede Globo, foi retirado do ar.

Na internet páginas diversas publicaram matérias em repúdio à charge. 0 site Folha de dourados, ${ }^{74}$ por exemplo, no dia 31 de janeiro de 2013, veiculou uma notícia intitulada Incêndio boate Kiss - entre a emoçâo e o escárnio, em que declarou que a charge era "uma referência direta aos mortos da boate Kiss, de Santa Maria, que o mais reles pasquim de quinta categoria teria pejo de exibir". Acrescentou, ainda, que a publicaçâo se tratava de um "monumento de mau gosto". A notícia da Folha de dourados expôe ainda que:

[...] Em episódios de risco de má interpretaçăo, a medida mais salutar é eliminar as fontes possíveis de equívocos. No caso da tragédia de Santa Maria, o mais correto seria dispensar os chargistas de terem que caminhar na corda bamba. Mesmo porque uma seçấo de humor é a última coisa que o leitor gostaria de ver num jornal em uma ocasiăo como essa.

Nessa declaraçăo, percebemos a posiçăo valorativa voltada ao entendimento de charge como discurso de humor. Como já mencionamos, os dicionários Priberam e Houaiss descrevem o termo charge como uma ilustraçāo ou desenho humorísticos. Será que a charge tem sempre esse traço de humor presente em sua formaçâo? Observando a charge em questăo, podemos dizer que há elementos verbais e/ou náo verbais que remetem ao humor? Entendemos que nâo.

73 Muitas cidades decretaram luto por Santa Maria, inclusive cancelando ou transferindo festejos como o Carnaval. Disponível em: <http://www.lavras.mg.gov.br/?p=10247>; <http://www.itaqui.rs.gov.br/ noticias/2013/01/prefeito-decreta-luto-oficial-no-municipio-em-razao-da-tragedia-de-santa-maria. html>; <http://zh.clicrbs.com.br/rs/noticias/noticia/2013/02/luto-por-santa-maria-cancela-carnavalem-mais-de-30-municipios-gauchos-4037893.html>. Acesso em: maio de 2014.

74 Disponível em: <http://www.folhadedourados.com.br/noticias/brasil-mundo/incendio-na-boate-kissentre-a-emocao-e-o-escarnio>. Acesso em: 17 de maio 2014. 
No site Coletivova.net, ${ }^{75}$ em uma publicaçăo do dia 26 de fevereiro de 2013, foi noticiado que:

Marco Aurélio entrou em férias logo após a publicaçăo de charge alusiva ao incêndio da boate Kiss, em Santa Maria [...]. O trabalho repercutiu mal entre os leitores e internautas, que em comentários nas redes sociais expressaram insatisfaçăo com a publicaçăo, sobre a qual se referiam como um ato de insensibilidade e desrespeito aos sobreviventes, aos amigos e aos familiares das vítimas.

Se essa notícia procede, talvez o jornal tenha decidido afastar o chargista como forma de atenuar as críticas. Frente a essa problemática, pensemos qual é o lugar da charge como gênero de opiniăo? Se houve essa repercussăo negativa a ponto de afastar o chargista, é porque năo estamos lidando com um discurso insignificante. $O$ gênero chárgico tem, sim, circulaçâo no meio social. Isso mostra que um discurso complexo como a charge tem impacto na vida social por mexer com valores, com sentimentos, com subjetividades.

Outra questăo necessária é, mais uma vez, levantar a reflexăo acerca dos sentidos oriundos da tensáo dos discursos que emergem no meio social. No caso da referida charge, essa tensâo acontece, por um lado, em termos de produçăo, entre as vozes que refletem e refratam a tragédia de Santa Maria e, por outro, em termos de recepçâo, entre as vozes que associam charge a discurso humorístico. A vinculaçăo da charge ao humor sugere valoraçóes negativas, fazendo com que seu leitor, ciente da situaçăo enunciativa concreta que deu origem à charge, valore negativamente a construçâo de sentido que relaciona charge-humor-tragédia, levando-o a tomar atitudes responsivas de desacordo, desagrado.

Acerca da mesma temática, trazemos para discussâo uma charge de autoria de Chico Caruso, publicada na primeira página do jornal 0 Globo ${ }^{76}$ do dia 28 de janeiro de 2013. A charge também foi veiculada no mesmo dia, na seçăo humor, pelo Blog do Noblat, ${ }^{77}$ um espaço do colunista do jornal O Globo, Ricardo Noblat.

Sob a forma de um quadro, temos uma cena que dialoga com o incidente da cidade de Santa Maria. Na charge vemos uma figura humana feminina vestida com camisa vermelha, calça preta e sapatos de salto. Ela leva as măos à cabeça em alusăo ao sentimento de espanto. A sua frente está um quadrado de ferro com grades, que nos remete a uma jaula, tomada por fogo. Desse espaço saem máos humanas posicionadas para cima como que pedindo ajuda e bocas abertas como de pessoas que gritam. Centralizada na parte inferior da charge, há uma voz que exclama: - Santa Maria!

75 Disponível em: <http://www.coletiva.net/site/noticia_detalhe.php?idNoticia=48854> Acesso em: 17 de maio 2014.

76 Disponível em: 〈http://memoria.oglobo.globo.com/jornalismo/primeiras-paginas/o-horror-na-boate-8978056> Acesso em: 17 de maio de 2013.

77 Disponível em: <http://oglobo.globo.com/pais/noblat/posts/2013/01/28/a-charge-do-chico-caruso-484094. asp>

Acesso em: 17 de maio 2014. 
Figura 2 - Santa Maria!

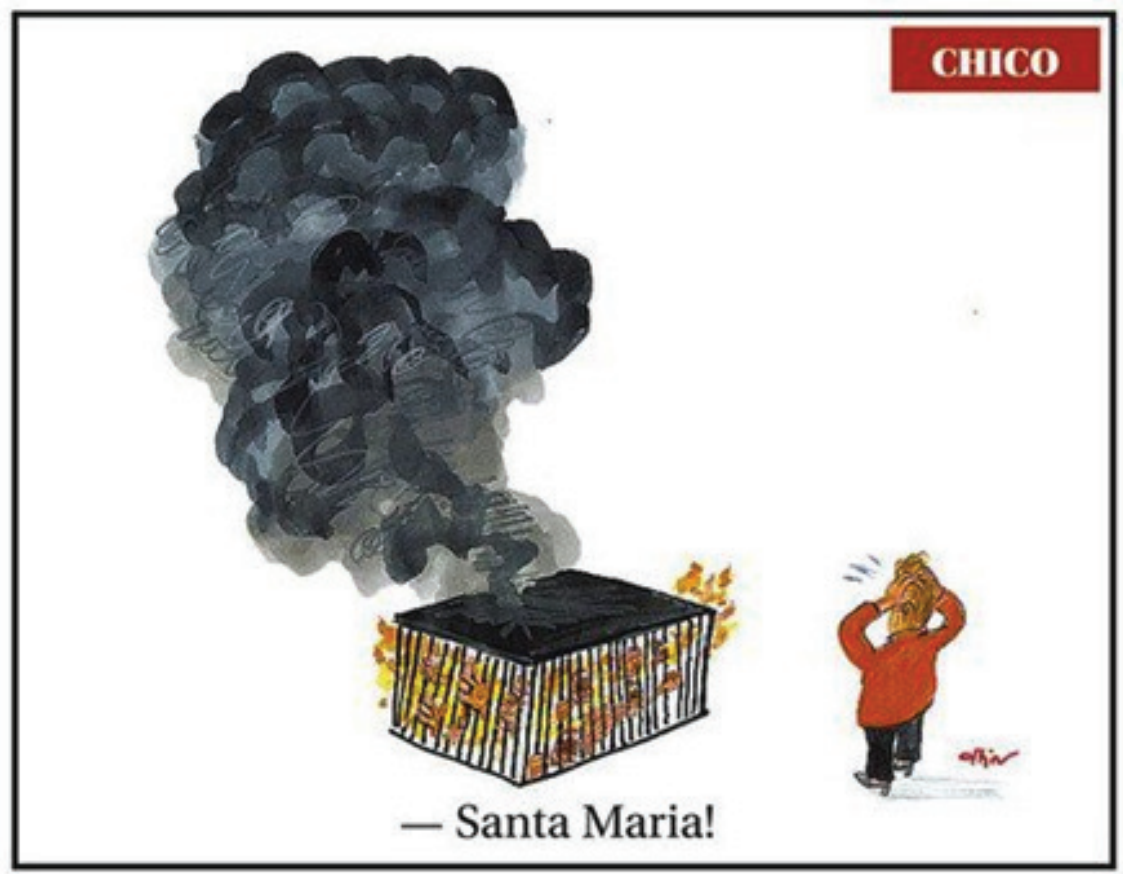

Fonte: Blog do Noblat,17/05/2014

Com base na observaçăo da charge (fig. 2), podemos perceber que há signos ideológicos que refletem a situaçâo do incêndio na boate gaúcha e refratam sentimentos como agonia e tristeza. Essa apreciaçăo dá-se em razăo de as pessoas estarem presas em um quadrado de ferro, o que simboliza a năo possibilidade de fuga. Também a julgar pelos signos ideológicos máos levantadas pedindo ajuda e bocas abertas como de pessoas que gritam. Tudo isso nos leva a concluir, a partir do valor que esses signos têm na sociedade em que estamos inseridos, que as pessoas pediam por socorro.

Nessa cena, temos ainda um marcador de diálogo, centralizado na parte inferior da charge, que diz "Santa Maria!". Introduzida por um travessăo, essa marca de diálogo expressa uma voz social que pode refletir e refratar três entonaçóes distintas, mas sobrepostas: a) interjeiçaáo de espanto que reforça os elementos năo verbais (figura humana leva as máos à cabeça em sinal de susto, assombro), b) interjeiçăo de temor expressa pela invocaçáo de nomes santos (a exemplo de outras expressôes fixadas na língua com a mesma valoraçăo: "santo Deus", "meu Deus", "minha nossa Senhora") e c) referência à cidade gaúcha Santa Maria.

Outro signo ideológico que podemos perceber săo as cores da vestimenta da figura humana que aparece na charge. As cores preto e vermelho podem refletir o Partido dos trabalhadores (PT) e refratar um possível envolvimento deste no incêndio da boate em Santa Maria. Esse signo ideológico pode também refratar questōes políticas de diferentes instâncias porque o Partido dos Trabalhadores, em teoria, tende a ideias de esquerda, é o partido do presidente do Brasil, e o jornal e o blogue em que a charge foi publicada podem ser compreendidos como tendo uma orientaçăo de direita.

Assim, a charge pode constituir uma crítica ao partido que estava no poder - quando de sua publicaçăo - e que, em tese, teria controle de situaçôes como essa e é negligente 
em năo fiscalizar os estabelecimentos - seja na instância que for, afinal, os governos federal e estadual eram na época da tragédia dirigidos por petistas. A própria capa do jornal $O$ Globo em que a charge foi publicada nos dá subsídio para essa valoraçâo. Com a manchete "Descaso mata 231 jovens no sul”, conforme podemos ver na figura 3, a capa apresenta diferentes discursos sobre a tragédia na boate gaúcha.

Na composiçấo do enunciado que ilustra a capa do jornal, a escolha do signo ideológico verbal descaso diz muito sobre o ponto de vista que está sendo construído. Descaso e mata compóem uma valoraçáo de acusaçâo, haja vista que o enunciado está tomado por juízos que reverberam vozes de desprezo, desconsideraçăo somados ao uso afirmativo do verbo matar. É importante relacionar esses signos ideológicos ao contexto em que aparecem: a capa desenha um discurso na trama de um mosaico que coaduna os signos descaso, o verbo matar no presente usado para construir uma afirmaçâo (mata), as fotos da presidente da República e do entâo governador do estado do Rio Grande do Sul (ambos petistas) e a charge de Caruso, que reverbera todas as vozes mostradas nesta análise.

Figura 3 - Descaso mata 231 jovens no Sul

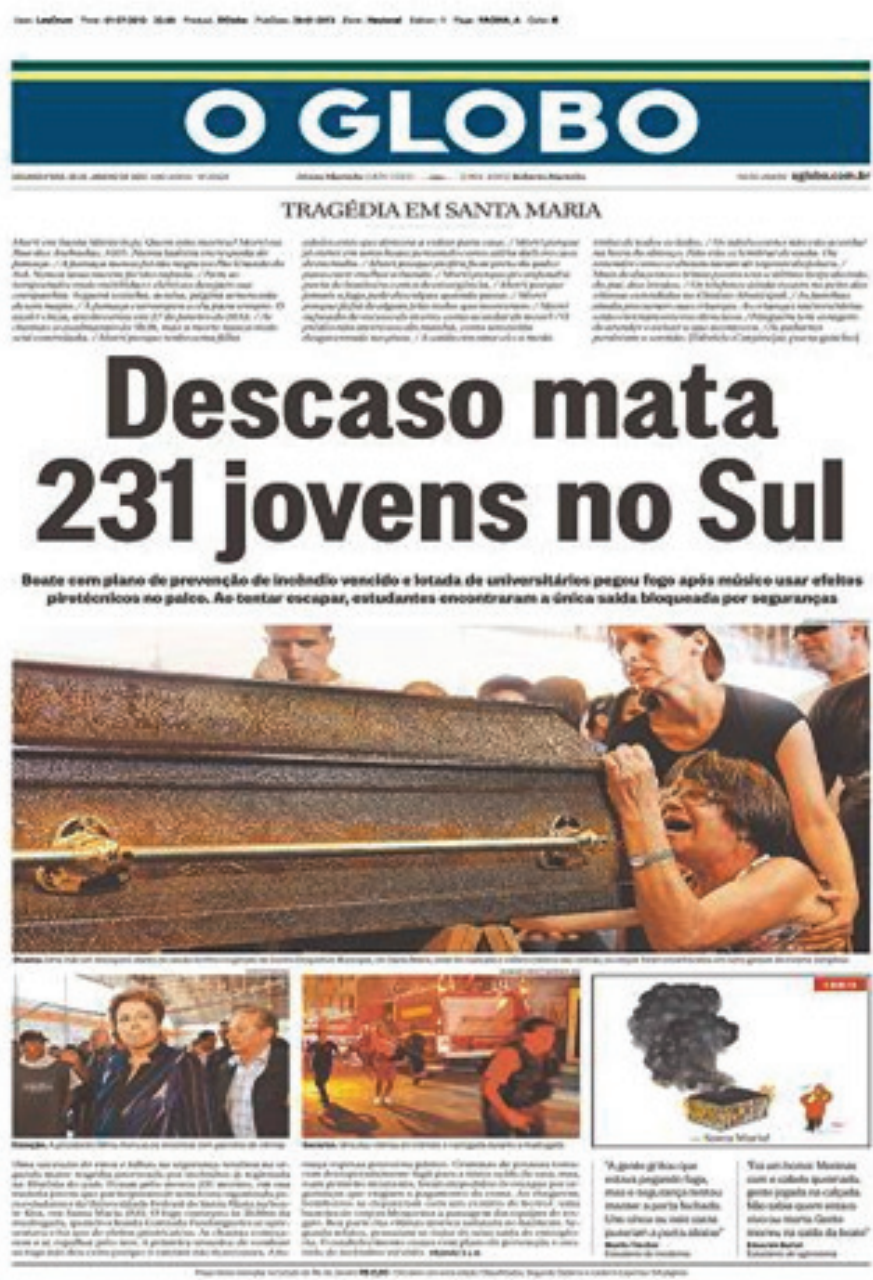

Fonte: O Globo, 18/04/2014. 
As orientaçóes de esquerda e de direita no que tange à política formam um tenso confronto ideológico. O jornal O Globo, assim como o Blog do Noblat, é vinculado à Rede Globo que, por sua vez, pelo teor de suas publicaçóes, podemos entender que tem orientaçăo política de direita. Isso significa dizer que, de alguma forma, a publicaçâo da charge nesse espaço pode sugerir o envolvimento do PT no incêndio da boate, seja de maneira indireta pela náo fiscalizaçăo, por exemplo, das licenças de funcionamento da casa noturna, seja por razóes de omissâo de socorro por parte das autoridades competentes.

Isso pode se justificar pelo fato de a figura humana que aparece na charge estar apenas observando a situaçâo. As mâos e bocas que aparecem refletem e refratam um pedido de ajuda, mas a pessoa na ilustraçăo observa com espanto a situaçăo de longe. Náo age em prol das vítimas. Além disso, no plano gráfico, ela está posicionada levemente acima da perspectiva de enquadramento da jaula pegando fogo, configurando afastamento da situaçăo.

Na leitura inicial dessa charge, com base em seus elementos verbo-visuais, poderíamos dizer que a figura humana que aparece assombra-se com a situaçăo da tragédia. Assim, teríamos uma leitura linear sobre o incêndio na Boate Kiss. Essa seria uma interpretaçâo possível, mas náo estaríamos considerando questōes como: quem essa pessoa representa, por que essa figura humana foi assim retratada; por que a tragédia foi ilustrada dessa perspectiva; onde foi publicada a charge etc.

Ao relacionar os elementos da charge ao contexto histórico da enunciaçâo e considerando as demais possíveis vozes que atravessam o discurso, em uma leitura crítica, podemos pensar que talvez o incidente tenha sido um motivo para manifestar, de modo velado, confrontos ideológicos de esferas discursivas diferentes (orientaçăo partidária), conforme apresentamos em nossa apreciaçáo. Assim, a partir dessas reflexôes, podemos perceber na charge vozes referentes ao incêndio da boate em Santa Maria, vozes acerca do discurso político e também vozes que entoam um discurso religioso (por meio da interjeiçấo que tanto pode ser considerada uma expressăo fixa na língua, entoando aí valoraçăo de espanto; tanto por invocar ajuda divina, por meio do uso de um signo religioso, a virgem Maria).

A publicaçăo da charge de Caruso foi alvo de comentários, ${ }^{78}$ em alguns sites, como é o caso do Portal Fórum, que através de um espaço intitulado Blog do Rovai veiculou no dia 28 de janeiro de 2013 uma matéria intitulada Jornalismo urubu: Chico Caruso, Noblat e a canalhice de fazer humor com Santa Maria. ${ }^{79} \mathrm{O}$ autor do texto menciona que a charge é vista como um insulto. Acrescenta, ainda, a indignaçáo de ter no Blog do Noblat a charge vinculada à palavra humor e que sua publicaçăo foi "uma tentativa barata de agredir a presidente e politizar a tragédia".

O site Observatório da imprensa, 80 por sua vez, publicou no dia 29 de janeiro um artigo intitulado "A emoçấo útil e a charge infeliz". Nele podemos ler que:

78 Só no Blog do Noblat existem 252 comentários repudiando a publicaçâo da charge.

79 Disponível em: <http://www.revistaforum.com.br/blogdorovai/2013/01/28/jornalismo-urubu-chico-caruso-noblat-e-acoragem-de-fazer-humor-com-santa-maria/>. Acesso em: 17 de maio 2014.

80 Disponível em: 〈http://www.observatoriodaimprensa.com.br/news/view/a_emocao_util_e_a_charge_infeliz >

Acesso em: 18 de maio de 2013. 
Năo há dúvida de que qualquer discurso comporta mais de uma interpretaçăo, mas exatamente por isso o argumento de Noblat ${ }^{81}$ não se sustenta: porque a desqualificação de seus interlocutores ao final - "vocês não sacaram nada, nadinha" - supõe um sentido único e, a rigor, muito improvável, dada a sistemática postura do jornal contra o governo petista. (Comentário 1)

A declaraçấo de que "[...] qualquer discurso comporta mais de uma interpretaçâo [...]" faz referência ao comentário do colunista Noblat, veiculado em seu endereço eletrônico Blog do Noblat, em razăo das críticas à publicaçăo da charge de Caruso.

As charges que dialogam com o incêndio da boate em Santa Maria foram alvos de críticas por terem sido vinculadas em um momento delicado em que a populaçăo brasileira sofria por conta da tragédia na cidade gaúcha. Muitas pessoas sensibilizadas com a dor das famílias que perderam filhos, conhecidos, amigos, pessoas que lhes eram próximas tomaram as charges como agressivas, como uma forma de insulto.

As charges dialogam com o incidente, refletem a situaçăo vivida pelas vítimas. Por outro lado, refratam sentidos diferentes porque cada indivíduo aproximou-se de alguma forma da dor causada pela tragédia. Assim, as críticas apareceram sobre o entendimento de que a charge é um gênero de humor e năo cabe humor frente à morte. No horizonte social em que nos encontramos enquanto sociedade brasileira, a morte é normalmente valorada como um período de sofrimento e condenaçáo. As vozes que estăo "autorizadas" pelos valores fixos que conduzem os comportamentos sociais sâo aquelas que ressoam pêsames, condolências e sentimentos de lamento frente às perdas.

Após analisarmos os discursos que colocamos em questăo, foi possível perceber que a produçấo do sentido năo está somente em um dos parceiros comunicativos, isto é, nâo é de domínio do locutor (embora ele tenha um projeto enunciativo, o sentido nâo é de sua exclusividade), tampouco responsabilidade única do interlocutor, no entendimento de que ele nâo pode realizar qualquer interpretaçâo do discurso que lhe chega. O sentido, pois, é edificado na relaçăo entre locutor, objeto e interlocutor sempre com base nas relaçōes dialógicas que se apresentam na cadeia discursiva. Isso quer dizer que o ouvinte, por exemplo, náo pode tomar isoladamente o discurso que recebe, tem de compreendê-lo na continuidade dos discursos já-ditos.

De toda forma, a relaçăo dialógica que promove a produçâo dos sentidos em circulaçăo pode se dar com os discursos selecionados pelo interlocutor, devido à valoraçâo que ele faz do discurso ao qual está tomando uma atitude responsiva ativa. Nessa perspectiva, essa seleçâo de discursos e as relaçôes com ele feitas podem originar leituras diferentes daquelas apontadas pelo projeto enunciativo do locutor que o interlocutor responde, causando sentidos polêmicos, conforme foi discutido durante as análises.

81 "Os que criticam a charge do Chico Caruso perderam o bom senso, a se levar em conta a violência com que escrevem. O que a charge tem de chocante, de desrespeitosa com quem quer que seja? Dilma pôr as mắos na cabeça e dizer "Santa Maria"? Isso é um absurdo? [...] Dilma năo faz política quando grita "Virgem Maria". Nem a charge sugere isso. Dilma revela seu desespero. Sua inconformidade. Que é nossa também. Ela náo tem culpa alguma pelo que aconteceu. Foi solidária com todos os que sofrem. Esteve em Santa Maria. Sinceramente se comoveu com o que viu. O que tem mais na charge? A boate transformada numa prisâo? As janelas gradeadas? As măos crispadas dos que ali ficaram retidos clamando por ajuda? Mas năo foi mesmo numa prisâo em que a boate se transformou? Numa armadilha? Numa ratoeira? Perdáo, mas vocês năo sacaram nada, nadinha" (extraído de Observatório da imprensa). 


\section{CONSIDERAÇÕES FINAIS}

Charges que abordam a temática da morte tendem a serem polêmicas: ou săo vistas como insulto ou entendidas como homenagem às vítimas. Como a charge é um gênero que se constitui a partir de acontecimentos sociais que sejam contemporâneos a ela, fez-se oportuno o questionamento de como se dá a construçăo dialógica dos sentidos, considerando a produçăo e recepçăo do discurso, em uma charge tida como polêmica por tratar sobre morte trágica.

Nessa perspectiva, este trabalho visou a examinar de que forma diferentes vozes sociais que atravessam charges polêmicas sobre morte trágica se engendram e refletem e refratam sentidos no discurso. Para tanto, analisou-se como recorte de pesquisa duas charges, uma de Marco Aurélio e outra de Chico Caruso em diálogo com discursos-resposta a ela relacionados, todos veiculados em meio digital em 2013 e que fazem referência a fatos divulgados pela mídia brasileira também nesse ano. Como embasamento teórico, recorreu-se às ideias postuladas pelo Círculo de Bakhtin.

Quanto às consideraçōes finais, destaca-se que charges que dialogam com incidentes trágicos, geralmente, săo alvos de críticas por serem veiculadas em um momento delicado. Assim, sublinha-se que năo só os elementos culturais săo importantes para a valoraçăo que se faz da charge como o momento histórico da enunciaçáo em que ela é edificada importa para compreendê-la, bem como entender a polêmica de sua recepçâo. 


\section{REFERÊNCIAS}

BAKHTIN, M/VOLOCHÍNOV, V. N. Marxismo e filosofia da linguagem. Traduçăo: Michel Laud; Yara Frateschi. Săo Paulo: Hucitec, 2009.

FARACO, Carlos Alberto. Linguagem e diálogo: as ideias linguísticas do Círculo de Bakhtin. Săo Paulo: Parábola, 2009.

SAUSSURE, Ferdinand de. Curso de Linguística Geral. Traduçâo: Antônio Chelini, José Paulo Paes e Izidoro Blikstein. Sâo Paulo, Cultrix: 1999.

VOLOCHÍNOV, V. A. A palavra na vida e na poesia. Introduçâo ao problema da poética sociológica (1926).In: BAKHTIN, M. Palavra própria e palavra outra na sintaxe da enunciaçáo. Săo Carlos: Pedro e Joăo Editores, 2011. 